\title{
社交不安症状と対人的自己効力感が大学生の ひきこもり親和性に与える影響 1 (1,2),3)
}

\author{
新 井 博 達 ${ }^{4}$ \\ 北翔大学大学院人間福祉学研究科 \\ 弘 中 由 麻 \\ 札幌はな発達デイサービス \\ 近 藤 清 美 ${ }^{5)}$ \\ 東京福祉大学大学院心理学研究科
}

本研究では，社交不安の認知モデル（Clark \& Wells, 1995）に基づき，ひきこもり親和性と社交不安症状 と対人的自己効力感の関連について検討を行った。大学生 246 名（男性101名, 女性 145 名）を対象として, ひきこもり親和性を測定する尺度, Liebowitz Social Anxiety Scaleの日本語版，対人的自己効力感尺度を用 いた質問紙調查を実施した。共分散構造分析の結果から，社会場面における恐怖感／不安感が，ひきこも り親和性に対して直接的な正の影響を与えていることが示された。その一方で，社会場面における回避が， ひきこもり親和性に対して直接的な影響を与えていることは示されなかった。また，対人的自己効力感は， 社会場面に扔ける恐怖感／不安感を介して，ひきこもり親和性に対して間接的な負の影響を与えているこ とが示された。以上の結果から，ひきこもり親和性の高い人々に対する予防的な介入として，対人的自己 効力感を高めるような働きかけが有効である可能性が示唆された。

キーワード : ひきこもり親和性, 社交不安, 対人的自己効力感, 大学生

\section{問 題}

ひきこもりとは,「さまざまな要因の結果とし て社会的参加（義務教育を含む就学，非常勤職を 含む就労，家庭外での交遊など）を回避し，原則 的には 6 力月以上にわたっておおむね家庭にとど まり続けている状態（他者と交わらない形での外 出をしていてもよい）」である（齊藤・中島・伊 藤・皆川・弘中・近藤 $\cdot$ 水田 $\cdot$ 奥村 $\cdot$ 清田 $\cdot$ 渡

1）本論文は，第一著者が2012年度に北海道医療大学心 理科学部へ提出した卒業論文の一部を加筆・修正し たものである。

2) 本論文の一部は, 日本心理学会第 77 回大会（2013 年）において発表された。

3）本調査にご協力くださいました皆様に心よりお礼申 し上げます。

4）現所属：北海道社会福祉事業団太陽の園

5) 現所属：帝京大学文学部
部·原田・斎藤・堀口，2010）。ひきこもりは, 国内で少なくとも255,510もの世帯に存在するこ とが推定されており（川上・大野・竹島・堀口・ 立森・深尾，2008），日本社会において大きな問 題となっていることがうかがえる。また，ひきこ もりは, 日本だけでなく海外においても問題に なっている (e.g., Chong \& Chan, 2012; Teo, 2012)。 Kato, Shinfuku, Fujisawa, Tateno, Ishida, Akiyama, Sartorius, Teo, Choi, Wand, Balhara, Chang, Chang, Shadloo, Ahmed, Lerthattasilp, Umene-Nakano, Horikawa, Matsumoto, Kuga, Tanaka, \& Kanba (2011) による, 国内外の9力国 の精神科医を対象にした調査では，そのすべての 国において，ひきこもりの事例が存在しているこ とが報告されており，ひきこもりは今後，国際的 にも重要な問題になる可能性があると推測される。 ひきこもりは, 様々な精神障害との関連が報告 
されている。例えば, 山梨県・岩手県・石川県 · 埼玉県・和歌山県といった全国 5 力所の精神保健 センター・こころの健康センターに，ひきこもり 本人が来談した 152 事例のうち, 125 事例 (82.2\%) に対して，DSM-IV-TRに基づき診断がなされて いる（近藤·宮沢・境・清田・北端 $\cdot$ 黑田・黑 澤·宮田，2009）。同研究では，ひきこもり事例 に対する診断として, 統合失調症, 気分障害, 不 安障害, 適応障害, 知的障害, 広汎性発達障害, パーソナリティ障害といったものが挙げられてい る。

このような, ひきこもりの背景となる心理的問 題の中の 1 つして, 社交不安障害 (Social Anxiety Disorder：SAD）がある。社交不安障害 とは，「恥ずかしい思いをするかもしれない社会 的場面または行為場面に対する顕著で持続的な恐 怖」によって特徵づけられる疾患のことである (American Psychiatric Association, 2000)。ひき こもりとSADは区別される用語であるものの, 両者の関連を示した研究は多数存在している (e.g., Lee, Lee, Choi, \& Choi, 2013; Nagata, Yamada, Teo, Yoshimura, Nakajima, \& van Vliet, 2011 ; 境 ·川原・木下・久保・岩松・NPO 法人 全国引きこもり $\mathrm{KHJ}$ 親の会, 2009)。例えば，ひ きこもり状態にある人は, 社交不安の程度が統制 群よりも有意に高いこと（Lee et al., 2013）や $\mathrm{SAD}$ を持つ人と同程度に高い不安を感じている 場合が多いこと（境他，2009）が指摘されている。 以上より，本研究では，ひきこもりに関連する要 因としてSADに着目した。

SADについて, 認知行動論的観点から説明し た代表的なモデルとして, Clark \& Wells (1995) の研究がある。同研究によると, SADを維持す る要因として, 安全確保行動 (safe behavior) の 存在が指摘されている。安全確保行動とは, 社会 的な恐怖場面で生じる不安を十分に軽減したり, 破局的な結果をうまく避けるために用いられる行 動である（Clark \& Wells, 1995）。この安全確保
行動は, 恐れている社会的場面を避ける行動（恐 怖場面からの回避行動）と，恐れている場面にい つづけながら, 破局的な結果が起こらないように 行う行動（恐怖場面内での回避行動）の2つに大 別することができる（岡島・金井・陳・坂野, 2007）。ひきこもりは「社会的参加（義務教育を 含む就学, 非常勤職を含む就労, 家庭外での交遊 など）を回避」（齋藤他，2010）している状態で あることを踏まえると，2つの安全確保行動のう ち，社会的場面そのものを回避する恐怖場面から の回避行動の方が，ひきこもりの状態像をより反 映しているものと考えられる。よって, 本研究で は，2つの安全確保行動のうち，恐怖場面からの 回避行動に着目し，これを社会場面における回避 として記述する。

また，Clark \& Wells（1995）によると，SAD を持つ人は，他者に対して良い印象を与えようと するが，社会的場面における振る舞い方や自分自 身に関する否定的な信念を持つために, 社交不安 症状を呈することが指摘されている。このような 社交不安症状に関連する認知的要因の 1 つとし て, 社会場面における自己効力感 (self-efficacy) がある。自己効力感とは,「ある状況において, ある結果を達成するために必要な行動を自分が うまくできるかどうかの予期」のことである (Bandura, 1977)。Leary \& Atherton (1986) によ ると, Banduraの概念である自己効力感は, 社交 不安の領域に適用することが可能である。彼ら は, 社交不安の文脈における自己効力感を,「自 己呈示の効力予期 (self-presentational efficacy expectancy)」と名づけ，「他者によって否定的に 評価されることを防ぐために，自分自身をよく見 せることができるという信念」であると定義し た。また, 同研究では「自己呈示の結果予期 (self-presentational outcome expectancies)」を 「ある特定の行動をしたときに，自分はよい印象 を与えることができるという信念」であると定義 している。 
社会場面における自己効力感と社交不安症状の 間の関連を示す研究は, いくつか存在している (e.g., Gaudiano \& Herbert, 2006; 松尾·新井, 1998; Moe \& Zeiss, 1982; Muris, 2002)。 Schwarzer \& Jerusalem（1992）によると，社交不 安症状と社会場面における自己効力感の間には, $r=-.30$ から $r=-.66$ の相関があることが報告さ れている。加えて, 社会場面における自己効力感 は, 社交不安症状である恐怖・不安と回避との間 で，それぞれ負の関連を示すことが指摘されてい る Gaudiano \& Herbert, 2003)。以上より, 社 会場面に打ける自己効力感と社交不安症状の間に は，負の関連があることが予測される。

これらのことから, 本研究では, Clark \& Wells （1995）のモデルを踏まえて, 社交不安症状の感 情的側面として社会場面における不安, 社交不安 症状の行動的側面として社会場面における回避, 社交不安症状に関連する認知的側面として社会場 面に㧍ける自己効力感に着目し, それらの関連に ついて検討を行うことにする。

ところで，ひきこもりに関連する概念として， 近年では, ひきこもり親和群に関する研究がなさ れている。ひきこもり親和群とは,「実際にはひ きこもっていないにもかかわらず，ひきこもる人 の気持ちがわかるとか, 自分でもひきこもりたい と思う人々」のことであり（内閣府政策統括官, 2010)，ひきこもり親和性はこの傾向を表す用語 のことである。このひきこもり親和群は, 将来ひ きこもりに移行する可能性がある予備軍的な存在 であることが指摘されている（東京都青少年・治 安対策本部, 2008)。同研究によると, 精神的な 病気のために通院・入院した経験があった者は, ひきこもり群では $46.9 \%$, ひきこもり親和群では $21.2 \%$, 一般群では $4.7 \%$ であった。また, 趣味や 遊びのときだけ外出する者は，ひきこもり群では $50.0 \%$ ，ひきこもり親和群では $10.6 \%$, 一般群で は3\%であった。以上の結果から，ひきこもり親 和性の高い人は, ひきこもり群ほどではないが,
一般群よりも精神的な問題を多く抱えており, 外 出する機会も少ない状態にあることがうかがえ る。したがって, 渡部・松井・高塚 (2010) が指 摘するように, 実際にひきこもっている群に加え て，ひきこもりへの親和性を示す群に対するケア についても充実化し，ひきこもりに至る前段階で 介入する方法を探索することが必要であると考え られる。

さらに, 本研究では, ひきこもり親和群の中で も, 大学生における時期に着目した。全国の大学 教員を対象にした調査では, ひきこもり状態にあ る学生が, 推定で $0.3 \sim 0.9 \%$ （全国で $0.3 \sim 1.9$ 万 人）程度存在することが報告されている（水田・ 小林·石谷·安住·井出·谷口, 2009)。同研究 によると, 不登校・ひきこもり状態にある学生の 支援にうまくいっていないと感じている相談機関 が $87.5 \%$ にり, その理由の 1 つして, 早期発 見・対応の難しさが挙げられている。大学生の時 期におけるひきこもりを早期に予防する有効な方 策を見出すためにも，ひきこもり親和性の高い 人々の特徽を明らかにすることが必要である。

また，ひきこもり親和性の高い大学生に対して は, 在学中のひきこもりの予防だけでなく, 将来 の職場での不適応を見据えた支援が求められる。 ひきこもり状態にある人を対象とした調査では, 現在の状態に至った原因として, 職場不適応を挙 げたものが $28.1 \%$ 存在したことが報告されている （東京都青少年・治安対策本部，2008）。ひきこも り親和性の高い人々については, 職場を退職する 際に, 一般群よりも仕事上のストレスや肉体的 · 精神的健康の問題が生じやすいことが示唆されて いる（東京都青少年・治安対策本部, 2009）。大 学生は, 教育や支援を受ける機会が多い時期であ る。しかしながら, 大学を卒業した後に離職者と なったときには, 自らのキャリアに一時的な分断 が生じ, 学校㧍よび職業を管轄する行政サービス の隙間で適切な支援サービスを受けられないまま 放置されてしまう場合がある（東京都青少年・治 
安対策本部，2010)。したがって，仕事上でスト レスが生じやすい，ひきこもり親和性の高い人々 が，離職により，そのような状態に陥ることを未 然に防ぐためにも，大学教育の段階で可能となる 就労支援の方策を模索する必要がある。

ひきこもりと社交不安症状の関連を示す研究に ついては，前述してきたが，ひきこもり親和性と 社交不安症状の関連を示す研究もまた，いくつか 報告されている。まず，一般群から，ひきこもり 群・ひきこもり親和群を判別する要因の 1 つとし て, 対人恐怖の高さが指摘されている（渡部他, 2010)。内閣府政策統括官 (2010)の調査では,「他 人がどう思っているのかとても不安」という項目 では，ひきこもり親和群が $63.4 \%$,一般群が $26.8 \%$ という值を示した。同研究によると，「人に会う のが恐いと感じる」という項目についても，ひき こもり親和群が $44.3 \%$,一般群が $6.6 \%$ という值を 示している。加えて, 対人恐怖とSADには類似 点が存在する（金井・笹川・陳・嶋田・坂野, 2007; Kleinknecht, Dinnel, Kleinknecht, Hiruma, \& Harada, 1997; 大野, 2002) ことも考慮すると, これらの結果は，ひきこもり親和性と社会場面に おける不安の関連を示すものであると予測され る。

社交不安症状の一つである，社会場面における
回避とひきこもり親和群の関連を示唆する報告も また存在している。東京都青少年・治安対策本部 （2008）は，ひきこもり親和群は，一般群よりも 対立回避の傾向が強いことを明らかにしている。 さらに, 男性のひきこもり親和性高群は, 一般群 よりも友人に対する積極的な関与の回避の傾向が 強いことが報告されている（牧・海田・湯澤, 2010)。この結果から, ひきこもり親和性は, 社 会場面における回避との間においても, 関連を示 す可能性があると考えられる。

以上を踏まえて, 本研究では次のようなモデル を想定した（Figure 1)。はじめに, 社交不安症状 である社会場面における不安は，ひきこもり親和 性に対して，正の影響を与えていると仮定した (仮説 1)。次に, 社交不安症状である社会場面に おける回避は，ひきこもり親和性に対して，正の 影響を与えていると仮定した（仮説2）。そして， 仮説 $1 \cdot 2$ と社会場面における自己効力感と社 交不安症状の間の負の関連（Schwarzer＆ Jerusalem, 1992）を考慮して, 社会場面に打りる 自己効力感は, 社交不安症状を介し, ひきこもり 親和性に対して，負の影響を与えていると仮定し た（仮説 3$) 。$

本研究により，ひきこもり親和性と社交不安症 状と社会場面における自己効力感の関連が明らか

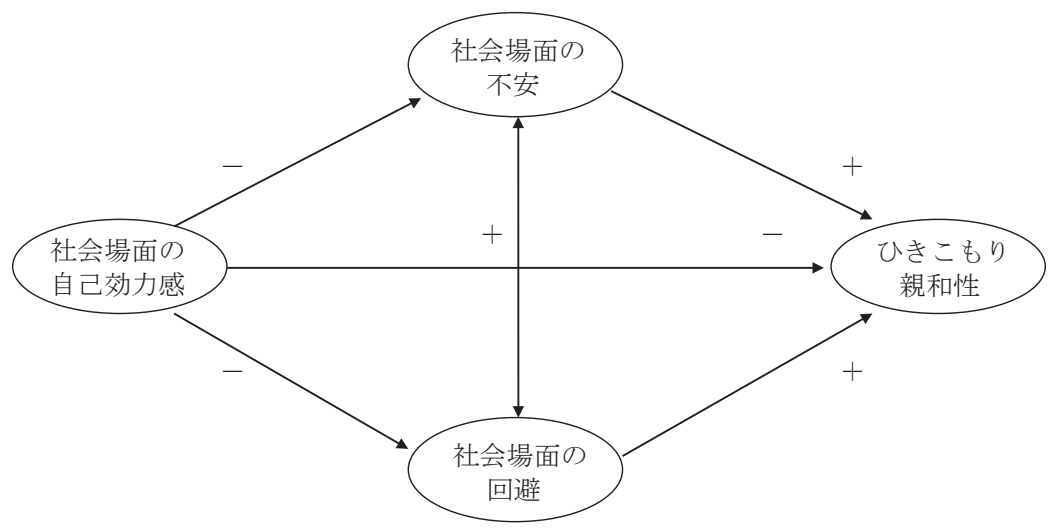

注.十は正，一は負の影響を示している。

Figure 1 ひきこもり親和性に影響を与える要因の仮説モデル（本研究における仮説モデル） 
になれば，ひきこもりに至る前段階で介入する方 法を探索することが必要であるとされている（渡 部他，2010）、ひきこもり親和群に対して，より 効果的な支援を提供するための新たな示唆が得ら れることが予測される。

\section{方法}

\section{調查協力者}

地方都市の私立大学生 259 名を対象に調查を 行った。そのうち, 久損值がない有効回答であっ た 246 名（男性 101 名; 女性 145 名, 平均年齢 $20.59 \pm 1.89$ 歳）を分析対象とした。

\section{調査手続き}

調査は, 2012 年 10 月 15 日から 10 月 25 日にか けて実施された。大学の講義終了後に調査用紙の 配布を行った。配布の際には, 調査協力の依頼と 研究の趣旨・倫理的配慮について, 書面と口頭で 説明を行った。

\section{調査材料}

デモグラフィックデータ＼cjkstart調査用紙のフェイス シートに記入年月日・性別・年齢について回答を 求めた。

ひきこもり親和性 ひきこもり親和性を評価す る尺度として，ひきこもりへの志向性や理解を示 す傾向を測定する質問項目（東京都青少年・治安 対策本部，2008）を使用した。ひきこもり親和性 を尋ねる4項目（「家や自室に閉じこもっていて 外に出たくない人たちの気持ちがわかる」，「自分 も，家や自室に閉じこもりたいと思うことがあ る」,「嫌な出来事があると, 外に出たくなくな る」,「理由があれば家や自室に閉じこもるのも仕 方がないと思う」）の合計点を「ひきこもり親和 性」得点とする。「1：はい〜 4:いいえ」の 4 件 法で, 可能な得点範囲は $4 \sim 16$ 点である。この尺 度は, 渡部他（2010）によって，信頼性と妥当性 の確認が行われている。

社交不安症状（恐怖感／不安感, 回避）社交 不安症状を評価する尺度として, SADの臨床症
状評価尺度である Liebowitz Social Anxiety Scale の日本語版 (LSAS-J) を使用した。朝倉・井上・

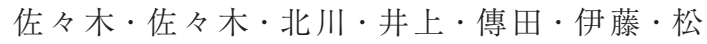
原・小山（2002）が作成したLSAS-Jは, 社交不 安症状を呈することが多い, 行為状況の 13 項目 と社交状況の 11 項目を含む, 合計 24 項目から構 成される。さらに, この 24 項目に対して, 恐怖 感/不安感と回避の程度をそれぞれ測定するた め, 合計 48 項目となる。これにより, LSAS-Jで は, 恐怖感 /不安感合計, 行為状況恐怖感/不安 感, 社交状況恐怖感 /不安感, 回避合計, 行為状 況回避, 社交状況回避の6つについて下位評価が 行われる。恐怖／不安感では「0：全く感じない ～3: 非常に強く感じる」, 回避では「0：全く回 避しない〜3：回避する(確率 $2 / 3$ または $100 \%) 」$ の 4 件法で評価する。よって, 可能な得点範囲は, 0〜144点である。この尺度は, 朝倉他（2002） により, 高い信頼性と妥当性が確認されている。

対人的自己効力感 社会場面の自己効力感を評 価する尺度として, 対人的自己効力感尺度を使用 した。大学生用の社会的スキル尺度（菊池, 1988）等を元に, 松本・坂野 (2000) が作成した。 対人的自己効力感とは,「対人的場面において, 適切な社会的行動を遂行することが，どの程度可 能かについての主観的な評価」(松尾・新井, 1998）である。この尺度は，5つの下位尺度で構 成されており, 関係開始の6 項目, 関係維持の 4 項目, 不快感主張の 3 項目, 自己開示の 3 項目, 拒否主張の 2 項目を含む, 合計 18 項目である。 $\lceil 1 ：$ 絶対できない〜 4 : 絶対できる」の 4 件法で 評価し, 可能な得点範囲は, $4 \sim 72$ 点である。こ の尺度は, 松本・坂野（2000）により，信頼性と 妥当性の確認が行われている。

\section{統計解析}

統計解析には, SPSS19.0 とAmos20.0を使用し た。第 1 に, 本研究で用いた各変数の記述統計量 を算出した。第2に, 各尺度について信頼性分析 を行った。第 $3 に$, 性差について調べるための $t$ 
検定を行った。第 4 に, 各尺度間の関連を調べる Pearsonの積率相関係数を算出した。最後に，本 研究の仮説モデルに基づいた共分散構造分析を行 い，モデルを評価・修正した。

\section{結＼cjkstart果}

\section{各尺度の記述統計量と信頼性係数}

各尺度の平均值, 標準偏差, 最小値, 最大值お
よび信頼性係数を Table 1 に示した。LSAS-Jとそ の全ての下位尺度, 対人的自己効力感とその下位 尺度である関係開始について，高い信頼性が確認 された $(\alpha=.82 \sim 94)$ 。また，対人的自己効力感 の下位尺度である関係維持と自己開示には, 中程 度の信頼性が確認された $(\alpha=.77 \sim 78)$ 。一方で, ひきこもり親和性と対人的自己効力感の下位尺度

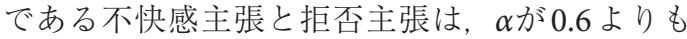

Table 1 各尺度の記述統計量拈よび信頼性係数

\begin{tabular}{lrrrrr}
\hline & 平均值 & 標準偏差 & 最小值 & 最大值 & $\alpha$ \\
\hline ひきこもり親和性 & 12.30 & 2.61 & 5 & 16 & .68 \\
LSAS-J & 48.09 & 28.39 & 0 & 128 & .97 \\
恐怖感/不安感合計 & 27.65 & 14.91 & 0 & 66 & .94 \\
行為状況恐怖感/不安感 & 12.89 & 7.78 & 0 & 36 & .89 \\
社交状況恐怖感/不安感 & 14.76 & 7.83 & 0 & 33 & .91 \\
回避合計 & 20.44 & 15.35 & 0 & 65 & .95 \\
行為状況回避 & 9.43 & 7.66 & 0 & 34 & .89 \\
社交状況回避 & 11.00 & 8.24 & 0 & 33 & .92 \\
対人的自己効力感 & 48.26 & 9.05 & 19 & 72 & .90 \\
関係開始 & 15.34 & 3.65 & 6 & 24 & .82 \\
関係維持 & 10.85 & 2.34 & 4 & 16 & .78 \\
不快感主張 & 7.31 & 2.12 & 3 & 12 & .65 \\
自己開示 & 8.32 & 2.07 & 3 & 12 & .77 \\
拒否主張 & 6.43 & 1.28 & 2 & .67 \\
\hline
\end{tabular}

注．LSAS-J：Liebowitz Social Anxiety Scale 日本語版。

Table 2 男女における各尺度の平均值, 標準偏差と性差

\begin{tabular}{|c|c|c|c|c|}
\hline & 男性 & 女性 & \multirow{2}{*}{$t$} & \multirow{2}{*}{$d f$} \\
\hline & 平均（標準偏差） & 平均（標準偏差） & & \\
\hline ひきこもり 親和性 & $11.68 \quad(2.89)$ & $12.72 \quad(2.31)$ & $3.13^{* *}$ & 244 \\
\hline LSAS-J & $44.58(26.70)$ & $50.52(29.35)$ & 1.62 & 244 \\
\hline 恐怖感／不安感合計 & $25.53(13.75)$ & $29.12(15.54)$ & 1.86 & 244 \\
\hline 行為状況恐怖感 /不安感 & $12.04 \quad(7.10)$ & $13.48 \quad(8.20)$ & 1.42 & 244 \\
\hline 社交状況恐怖感／不安感 & $13.50 \quad(7.25)$ & $15.64 \quad(8.11)$ & $2.13^{*}$ & 244 \\
\hline 回避合計 & $19.05(14.49)$ & $21.41(15.91)$ & 1.19 & 244 \\
\hline 行為状況回避 & $8.99 \quad(7.27)$ & $9.74 \quad(7.94)$ & 0.76 & 244 \\
\hline 社交状況回避 & $10.06 \quad(7.78)$ & $11.66 \quad(8.52)$ & 1.50 & 244 \\
\hline 対人的自己効力感 & $49.94 \quad(8.16)$ & $47.08 \quad(9.48)$ & $2.46^{*}$ & 244 \\
\hline 関係開始 & $16.05 \quad(3.40)$ & $14.84 \quad(3.75)$ & $2.58^{* *}$ & 244 \\
\hline 関係維持 & $11.25 \quad(2.12)$ & $10.58 \quad(2.45)$ & $2.22 *$ & 244 \\
\hline 不快感主張 & $7.83 \quad(1.89)$ & $6.95 \quad(2.20)$ & $3.27^{* * *}$ & 244 \\
\hline 自己開示 & $8.35 \quad(1.91)$ & $8.30 \quad(2.19)$ & 0.16 & 244 \\
\hline 拒否主張 & $6.47 \quad(1.25)$ & $6.41 \quad(1.30)$ & 0.35 & 244 \\
\hline
\end{tabular}

注. LSAS-J : Liebowitz Social Anxiety Scale 日本語版。 ${ }^{*} p<.05,{ }^{* *} p<.01,{ }^{* * *} p<.001$. 
大きく, 一応の内的整合性が見られたものの, や や低い信頼性が確認された $(\alpha=.65 \sim 68)$ 。

\section{各尺度における性差の検討}

男女に打ける平均値, 標準偏差を Table 2 に示 した。また, 男女間において, 各尺度の得点を対 応のない $t$ 検定によって比較した。その結果，ひ きこもり親和性 $(t(244)=3.13, p<.01), \quad$ LSAS-J の下位尺度である社交状況恐怖感 /不安感 $(t$ $(244)=2.13, p<.05)$ では, 女性の得点の方が, 有意に高かった。対人的自己効力感 $(t(244)=$ $2.46, p<.05)$ とその下位尺度である関係開始（ $t$
$(244)=2.58, p<.01)$, 関係維持 $(t(244)=2.22, p$ $<.05)$, 不快感主張 $(t(244)=3.27, p<.001)$ では, 男性の得点の方が, 有意に高かった。その他の尺 度の得点においては, 男女間で有意な差は見られ なかった。

\section{各尺度間の相関係数}

各尺度間における Pearsonの積率相関係数を Table 3 に示した。ひきこもり親和性は, LSAS-J との間で, 有意な弱い正の相関を示した $(r=.34$, $p<.001)$ 。また，ひきこもり親和性は， LSAS-J の下位尺度である恐怖感 $/$ 不安感合計 $(r=.34, p$

Table 3 各尺度間の相関係数

\begin{tabular}{|c|c|c|c|c|c|c|c|c|}
\hline & & 1 & 2 & 3 & 4 & 5 & 6 & 7 \\
\hline 1 & ひきこもり 親和性 & - & & & & & & \\
\hline 2 & LSAS-J & $.34^{* * *}$ & - & & & & & \\
\hline 3 & 恐怖感／不安感合計 & $.34^{* * *}$ & $.94^{* * *}$ & - & & & & \\
\hline 4 & 行為状況恐怖感／不安感 & $.32 * * *$ & $.90 * * *$ & $.96 * * *$ & - & & & \\
\hline 5 & 社交状況恐怖感／不安感 & $.34^{* * *}$ & $.89 * * *$ & $.96^{* * *}$ & $.83^{* * *}$ & - & & \\
\hline 6 & 回避合計 & $.29^{* * *}$ & $.94^{* * *}$ & $.76^{* * *}$ & $.74^{* * *}$ & $.72^{* * *}$ & - & \\
\hline 7 & 行為状況回避 & $.29^{* * *}$ & $.92^{* * *}$ & $.76^{* * *}$ & $.77^{* * *}$ & $.68^{* * *}$ & $.96^{* * *}$ & - \\
\hline 8 & 社交状況回避 & $.28^{* * *}$ & $.90 * * *$ & $.71^{* * *}$ & $.65^{* * *}$ & $.70^{* * *}$ & $.97 * * *$ & $.86^{* * *}$ \\
\hline 9 & 対人的自己効力感 & $-.26 * * *$ & $-.55^{* * *}$ & $-.51^{* * *}$ & $-.46^{* * *}$ & $-.51^{* * *}$ & $-.53 * * *$ & $-.50 * * *$ \\
\hline 10 & 関係開始 & $-.26^{* * *}$ & $-.53 * * *$ & $-.48^{* * *}$ & $-.41^{* * *}$ & $-.51^{* * *}$ & $-.51^{* * *}$ & $-.46^{* * *}$ \\
\hline 11 & 関係維持 & $-.25^{* * *}$ & $-.50 * * *$ & $-.48^{* * *}$ & $-.43^{* * *}$ & $-.48^{* * *}$ & $-.46^{* * *}$ & $-.44^{* * *}$ \\
\hline 12 & 不快感主張 & $-.18^{* *}$ & $-.34^{* * *}$ & $-.32 * * *$ & $-.28^{* * *}$ & $-.33^{* * *}$ & $-.33 * * *$ & $-.29^{* * *}$ \\
\hline 13 & 自己開示 & $-.19^{* *}$ & $-.36^{* * *}$ & $-.32 * * *$ & $-.32^{* * *}$ & $-.29^{* * *}$ & $-.35^{* * *}$ & $-.36^{* * *}$ \\
\hline \multirow[t]{2}{*}{14} & 拒否主張 & -.05 & $-.33 * * *$ & $-.31^{* * *}$ & $-.34^{* * *}$ & $-.26^{* * *}$ & $-.30 * * *$ & $-.33^{* * *}$ \\
\hline & & 8 & 9 & 10 & 11 & 12 & 13 & 14 \\
\hline 1 & ひきこもり 親和性 & & & & & & & \\
\hline 2 & LSAS-J & & & & & & & \\
\hline 3 & 恐怖感／不安感合計 & & & & & & & \\
\hline 4 & 行為状況恐怖感／不安感 & & & & & & & \\
\hline 5 & 社交状況恐怖感 /不安感 & & & & & & & \\
\hline 6 & 回避合計 & & & & & & & \\
\hline 7 & 行為状況回避 & & & & & & & \\
\hline 8 & 社交状況回避 & - & & & & & & \\
\hline 9 & 対人的自己効力感 & $-.52 * * *$ & - & & & & & \\
\hline 10 & 関係開始 & $-.53 * * *$ & $.87^{* * *}$ & - & & & & \\
\hline 11 & 関係維持 & $-.45^{* * *}$ & $.87^{* * *}$ & $.70 * * *$ & - & & & \\
\hline 12 & 不快感主張 & $-.35^{* * *}$ & $.76^{* * *}$ & $.54^{* * *}$ & $.58 * * *$ & - & & \\
\hline 13 & 自己開示 & $-.31^{* * *}$ & $.76^{* * *}$ & $.53^{* * *}$ & $.61^{* * *}$ & $.48^{* * *}$ & - & \\
\hline 14 & 拒否主張 & $-.25^{* * *}$ & $.51^{* * *}$ & $.31^{* * *}$ & $.39^{* * *}$ & $.32 * * *$ & $.32 * * *$ & - \\
\hline
\end{tabular}

注. LSAS-J: Liebowitz Social Anxiety Scale 日本語版。 ${ }^{* *} p<.01,{ }^{* * *} p<.001$ 
$<.001) \cdot$ 回避合計 $(r=.29, p<.001)$ との間にお いても，それぞれ有意な弱い正の相関を示した。 LSAS-Jの下位尺度である恐怖感／不安感合計と 回避合計との間には，有意な強い正の相関が認め られた $(r=.76, p<.001)$ 。加えて, 対人的自己効 力感は, LSAS-Jの下位尺度である恐怖感 /不安 感 $(r=-.51, p<.001)$ と回避 $(r=-.53, p<.001)$ の間でそれぞれ中程度の負の相関を示す一方で, ひきこもり親和性との間では有意な弱い負の相関 を示した。 $(r=-.26, p<.001)$ 。以上より，ひき こもり親和性と社交不安症状と対人的自己効力感 の間には，関連がある可能性が示唆された。

\section{共分散構造分析によるモデルの検討}

仮説モデル（Figure 1）に基づき，共分散構造 分析を行った。仮説モデルに対応する形で，潜在 変数として,ひきこもり親和性・恐怖感 /不安 感・回避・対人的自己効力感の 4 つを用いた。ま た，各潜在変数を規定する観測変数には，各尺度 の下位尺度もしくは質問項目を用いた。なお，本 研究では, 恐怖感 /不安感と回避の 2 因子間に, 有意な正の相関が認められたことから，両者の誤 差変数の間に共分散を仮定した。

各尺度における性差の $t$ 検定では，いくつかの
尺度得点に性差が認められた。したがって, 本研 究では, 最初に男女のデー夕に関して, 多母集団 同時分析によって, 比較を行った。その結果, 男 女に共通したパスが見出された。次に，その共通 のパスを取り出し, 恐怖感/不安感・回避・対人 的自己効力感・ひきこもり親和性の潜在変数間の パス係数, 恐怖感/不安感と回避の誤差変数間の 相関係数において, 男女間のパラメーターの差を 比較したところ，いずれの值においても，有意な 差が認められなかった。よって, 本研究では, 男 女を合わせたうえで，共分散構造分析を行った。

モデルの評価・修正の際には，10\%水準で有意 傾向が見られなかったパスを削除しながら, 適合 度を比較し, 分析を行った。最終的には, 以下の ようなモデルが採択された (Figure 2)。その結果, 最終的なモデルの適合度指標は, $\chi^{2}(61)=$ $167.619(p<.001), \mathrm{GFI}=.897, \mathrm{AGFI}=.847, \mathrm{CFI}$ $=.937, \mathrm{RMSEA}=.084$ となった。

重決定係数については, ひきこもり親和性が $R^{2}$ $=.15$, 恐怖感 $/$ 不安感が $R^{2}=.32$, 回避が $R^{2}=.31$, であった。次に，潜在変数間におけるパス係数を 示した。恐怖感/不安感からひきこもり親和性へ のパス係数は, 有意な正の值を示していた（ $\beta$

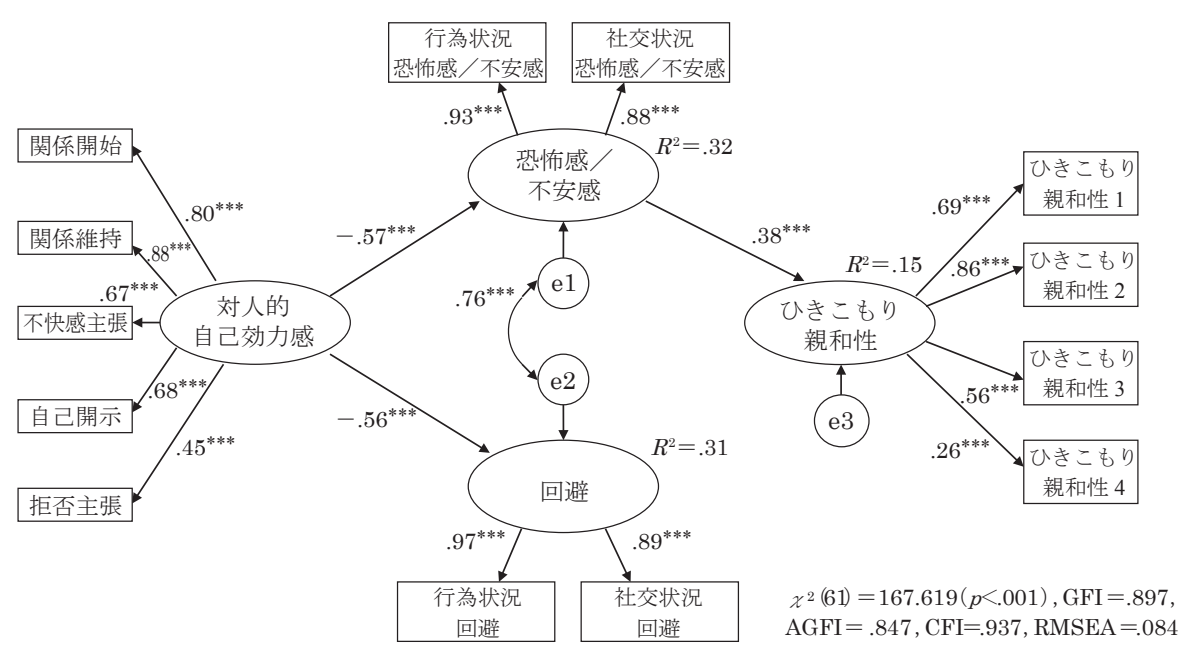

${ }^{*} p<.05,{ }^{* *} p<.01,{ }^{* * *} p<.001$

Figure 2 ひきこもり親和性に影響を与える要因の最終的なモデル 
$=.38, p<.001)$ 。その一方で, 回避からひきこも り親和性への直接的なパスは, 示されなかった。 すなわち，社交不安症状である社会場面における 不安が，ひきこもり親和性に正の影響を与えてい るとした仮説 1 は支持されたものの, 社交不安症 状である社会場面における回避が，ひきこもり親 和性に正の影響を与えているとした仮説 2 は支持 されなかったといえる。恐怖感／不安感と回避の 間には，有意な強い正の相関が認められた $(r$ $=.76, p<.001)$ 。また, 対人的自己効力感から恐 怖感 $/$ 不安感 $(\beta=-.57, p<.001)$ と回避 $(\beta=$ $-.56, p<.001)$ への゚ス係数は，それぞれ有意 な負の值を示していた。加えて, 対人的自己効力 感からひきこもり親和性へのパスは示されなかっ た。その一方で, 対人的自己効力感から恐怖感／ 不安感を介した，ひきこもり親和性への間接効果 に関しては, Sobel's testのデルタ法により, 有意 な負の值が示された $(\beta=-.22, p<.001)$ 。これ より, 社会場面における自己効力感は, 社交不安 症状を介し，ひきこもり親和性に対して，負の影 響を与えているとした仮説 3 は支持されたといえ る。

\section{考察}

本研究の目的は, ひきこもり親和性, 社交不安 症状の恐怖感/不安感と回避, そして対人的自己 効力感の間に, どのような関連があるのかを検討 することであった。

本研究では, 共分散構造分析により, 恐怖感 / 不安感は，ひきこもり親和性に対して正の影響を 与えていることが示され，仮設 1 が支持される結 果となった。すなわち, 社会場面における不安が 強い人ほど，ひきこもりへの親和性が高くなる可 能性がある。この結果は, ひきこもり親和性と対 人恐怖の関連（渡部他, 2010）や対人恐怖と社交 不安症状の関連（Kleinknecht et al., 1997）を示 す知見と合致したものであると考えられる。

次に, ひきこもり親和性と社交不安症状の 1 つ
である回避の関連について検討した。本研究で は, 共分散構造分析の結果から, 社会場面におけ る回避は,ひきこもり親和性に対して, 有意な影 響を与えていないことが示され，仮設 2 が支持さ れない結果となった。すなわち, ひきこもりへの 親和性の高い人々は, 必ずしも社会的な場面にお いて回避行動を示すわけではないと考えられる。 先行研究（東京都青少年・治安対策本部, 2008) では, ひきこもり親和群の $73.9 \%$ が, 仕事や学校 のために 3〜 4 日以上, 定期的な外出行動をとっ ていることが報告されており，ひきこもり親和性 の高い人々の多くは, 仕事や学校といった社会的 な場面を回避していないことがわかる。これは, 本研究の結果と類似した知見であると考えられ る。

その一方で, 他の先行研究では, ひきこもり親 和群は「対立回避」(東京都青少年・治安対策本 部, 2008) や「積極的な関与の回避」(牧他, 2010）の傾向が強いことが指摘されている。これ は,ひきこもり親和性に対して, 社会場面におけ る回避は影響を与えていないという本研究の結果 と, 一見矛盾するものである。このような不一致 が生じた要因としては, 先行研究における「対立 回避」や「積極的な関与の回避」と, 本研究にお いて使用したLSAS-Jの「回避」で測定している 内容に違いがあった可能性が挙げられる。「対立 回避」や「積極的な関与の回避」では, 質問項目 の多くが, 対人葛藤を回避するために自己主張を 控えることを意味するもので構成されていると考 えられる。その一方で, LSAS-Jは, 対人葛藤が 生じる際の自己主張を控えるような項目を一部含 むものの, 項目全体としては自己主張に限らず, 社交不安症状としての「恐怖場面からの回避行 動」を評価するものとなっており（岡島他，2007）, この違いが, 本研究の結果として反映された可能 性がある。以上を踏まえると, 社会的な場面にお いて高い不安を感じ, 自己主張を控えることで対 人葛藤を避ける傾向にあるが, 社会的な場面その 
ものは回避することなく, 社会参加を継続してい るものが，ひきこもり親和性の高い人々であると 予測される。

また, 本研究は, 社交不安症状としての2つの 安全確保行動のうち, 恐怖場面からの回避行動に 着目して，ひきこもり親和性との関連について, 検討を行ったものである。したがって，今後は， もう1つの安全確保行動であり, 社会的な場面に いつづけながら行われる, 恐怖場面内での回避行 動とひきこもり親和性の関連についても，新たに 検討していくことが必要である。

対人的自己効力感, 恐怖感/不安感, 回避の 3 変数の関連については, 対人的自己効力感が, 恐 怖感／不安感と回避に対して，それぞれ負の影響 を与えていることが示された。すなわち，社会場 面における自己効力感が高い人ほど, 社会場面に おける不安と回避の傾向が低くなる可能性があ る。先行研究では, 社会場面における自己効力感 と社会場面に打ける不安, 社会場面における自己 効力感と社会場面における回避の間で, それぞ れ負の関連が認められており (Gaudiano \& Herbert, 2003), この結果は, 本研究の結果と合 致するものであるといえる。

対人的自己効力感とひきこもり親和性の関連に ついては, 対人的自己効力感が, 社交不安症状の 恐怖感/不安感を介し, ひきこもり親和性に対し て，有意な負の影響を与えていることが示され た。すなわち，社会場面における自己効力感が高 まることで，ひきこもりへの親和性が低下する可 能性が示された。よって, 社会場面における自己 効力感は, 社交不安症状を介し, ひきこもり親和 性に対して負の影響を与えているとした仮説 3 は 支持されたといえる。先行研究では, これら $3 つ$ の変数に関する総合的な検討はなされておらず, 本研究により，明らかにされた知見だといえる。

渡部他（2010）は，ひきこもり親和群に対する ケアについても充実化し，ひきこもりに至る前段 階での介入方法を探索することが必要であると指
摘している。本研究では, 対人的自己効力感が恐 怖感／不安感を介して，ひきこもり親和性に負の 影響を与えていることが示された。すなわち, 対 人的自己効力感を高める介入を行うことで, 社会 場面の不安が減少し, 結果としてひきこもり親和 性を低下させる予防的な関わりが可能になると予 測される。先行研究では, 対人的自己効力感を向 上させた実践がいくつか存在している（e.g., 古 澤, 2005; 松枝 ·島田, 2010; 丹羽・濱口・村 上·嶋田·菅野, 2007; 佐藤 ·鈴木, 2012; 椎葉, 2002)。例えば, 小学 6 年生の学級で実施された 集団SSTによって, 社会的スキルだけでなく, 対 人的自己効力感が授業前よりも有意に高くなった （古澤，2005）。加えて，ひきこもり型の不登校児 童・生徒を対象としたキャンプ活動後には, 対人 的自己効力感が増加傾向にあったとされている （丹羽他，2007）。また, 大学生を対象にしたプロ グラムにおいても, 個人で取り組むワーク（松 枝・島田, 2010) やグループワーク（佐藤・鈴木, 2012）後に, 対人的自己効力感が有意に増加して いることが報告されている。以上のような実践 は, 児童・生徒あるいは学生の時期に介入するこ とで, 対人的自己効力感が高まる可能性を示すも のであるが，それに伴い社会場面に打ける不安が 下がり，ひきこもり親和群に対する効果的な支援 につながるものと考えられる。しかしながら，就 労前の段階に抢ける, 社会場面に打ける自己効力 感の向上が, 就労へと移行した後の職場不適応や 離職に対して予防的効果を持つかどうかは，未だ 明らかではない。よって, 大学生の対人的自己効 力感の向上が, 就労後の職場不適応や離職, そし てその後のひきこもり状態に与える影響について は，縦断的な形で検証を行う必要がある。また， 対象として, 大学生に特化した, 対人的自己効力 感を高めるための, さらなるプログラムの検討に ついても期待される。

今後の展開の 1 つしては, ひきこもり親和性 で確認されたモデルに関して，実際にひきこもり 
状態にある人においてもあてはまるかどうか, 検 討を行うことが重要であると考えられる。LSAS-J を用いた調査では, ひきこもり群は, SAD軽症 群に比べて, 回避の傾向が強いことを指摘されて おり（境・陳，2007）、ひきこもり親和群とは異 なった結果が得られる可能性がある。ひきこもり 親和群とひきこもり群の, 共通点と相違点が明確 になれば，両者に対して有効な支援を行うため の, 新たな知見が得られることが予測される。

また, ひきこもり親和群は, 将来ひきこもりに 移行する可能性があることが指摘されている（東 京都青少年・治安対策本部, 2008)。しかしなが ら，ひきこもり親和性が高い人の，ひきこもりへ の移行可能性については, 十分に検証されていな い現状にある。この点に関しては, 今後, 縦断的 研究による調査が望まれる。加えて, 渡部・松 井・高塚 (2011) は, ひきこもり親和群の中には, 実際にひきこもっている人とは, 異なる心性を持 つ群と類似した心性を持つ群が, 混在しているこ とを報告している。したがって，ひきこもり親和 性が高い人々のひきこもりへの移行可能性につい ては，ひきこもり親和群の下位分類（渡部他, 2011）についても着目し, 検討を行うことが必要 であると考えられる。

本研究では, 共分散構造分析の結果から, ひき こもり親和性において, 有意な重決定係数が得ら れたものの， $R^{2}$ の值は.15であったことから，そ の効果は限定的であり, その他の要因についても 考慮する必要があることがわかる。先行研究で は, ひきこもり親和群は, 一般群に比べて,「自 己決定への干渉拒否」·「うつ・罪悪感」·強 迫」·暴力」・依存」・家族との情緒的絆」と いった点において特徴が見られたことが報告され ている（渡部他, 2010）。ひきこもりでは, 生物・ 心理・社会的要因などの様々な要因が絡み合って いる（齋藤他， 2010）ことを考慮すると，ひきこ もり親和性においても同様に多様な要因について 考慮し, さらなる検討を行うことが必要であると
考えられる。

限界点として, 本研究は横断調査であり, 変数 間の因果関係については, 確認がなされていな い。本モデルの有効性を確認するためには, 今後, 縦断調査を用いて, 再検討を行うことが必要であ る。また, 本研究の調査結果は, 社交不安症状と 対人的自己効力感とひきこもり親和性の関係につ いて，大学生を対象にして検討したものである。 今後は, 大学生以外の年代の人々においても同様 の知見が得られるかどうか検討することが求めら れる。

\section{引用文献}

American Psychiatric Association (2000). Diagnostic and statistical manual of mental disorders. 4th ed. Text revision. Washington DC: American Psychiatric Publishing.

朝倉 聡·井上誠士郎 ·佐々木史 ·佐々木幸哉· 北川 信樹·井上猛・傳田健三・伊藤ますみ・松原 良次・小山司 (2002). Liebowitz Social Anxiety Scale (LSAS) 日本語版の信頼性および妥当性の検討 精神医学, 44, 1077-1084.

Bandura, A. (1977). Self-efficacy: Toward a unifying theory of behavioral change. Psychological Review, 84, 191-215.

Chong, S. S., \& Chan, K. (2012). A case study of a Chinese 'hikikomorian' in Canada - theorizing the process of hikikomorization. Journal of Special Education and Rehabilitation, 13, 99-114.

Clark, D. M., \& Wells, A. (1995). A cognitive model of social phobia. In R. G. Heimberg, M. R. Liebowitz, D. A. Hope, \& F. R. Schneier (Eds.), Social phobia: Diagnosis, assessment, and treatment. New York: Guilford Press pp. 69-93.

Gaudiano, B. A., \& Herbert, J. D. (2003). Preliminary psychometric evaluation of a new self-efficacy scale and its relationship to treatment outcome in social anxiety disorder. Cognitive Therapy and Research, 27, 537-555.

Gaudiano, B. A., \& Herbert, J. D. (2006). Self-efficacy for social situations in adolescents with generalized social anxiety disorder. Behavioral and Cognitive Psychotheraphy, 35, 209-223. 
古澤裕美（2005）。高学年児童に扔ける集団 SST の効果

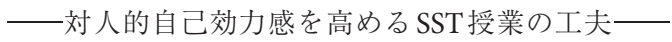
広島大学大学院心理臨床教育研究センター紀要, 4, 146-149.

金井嘉宏・笹川智子・陳 峻雯・嶋田洋徳 ·坂野雄 二 (2007). 社会不安障害傾向者と対人恐怖症傾向者 における他者のあいまいな行動に対する解釈バイア 又 行動療法研究, 33, 97-110.

Kato, T., Shinfuku, N., Fujisawa, D., Tateno, M., Ishida, T., Akiyama, T., Sartorius, N., Teo, A. R., Choi, T. Y., Wand, A. P. F., Balhara, Y. P. S., Chang, J. P. C., Chang, R. Y. F., Shadloo, B., Ahmed, H. U., Lerthattasilp, T., Umene-Nakano, W., Horikawa, H., Matsumoto, R., Kuga, H., Tanaka, M., \& Kanba, S. (2011). Introducing the concept of modern depression in Japan: An international case vignette survey. Journal of Affective Disorders, 135, 66-76.

川上憲人 · 大野 裕 - 竹島 正 ·堀口逸子 - 立森久照 深尾 彰 (2008). 平成 18 年度厚生労働科学研究費 補助金 (こころの健康科学研究事業)「こころの健康 についての疫学調査に関する研究」総括研究報告書

菊池章夫（1988）。思いやりを科学する川島書店

Kleinknecht, R. A., Dinnel, D. L., Kleinknecht, E. E., Hiruma, N., \& Harada, N. (1997). Cultural factors in social anxiety: A comparison of social phobia symptoms and Taijin Kyofusho. Journal of Anxiety Disorders, 11, 157-177.

近藤直司 - 宮沢久江 - 境 泉洋 - 清田吉和 - 北端裕 司・黑田安計・黑澤美枝 ·宮田量治（2009）。思春期 ひきこもりに扔ける精神医学的障害の実態把握に関 する研究平成 20 年度厚生労働科学研究費補助金 (こころの健康科学研究事業)「思春期のひきこもり をもたらす精神疾患の実態把握と精神医学的治療. 援助システムの構築に関する研究」

Leary, M. R., \& Atherton, S. C. (1986). Self-efficacy, social anxiety, and inhibition in interpersonal encounters. Journal of Social and Clinical Psychology, 4, 256-267.

Lee, Y. S., Lee, J. Y., Choi, T. Y., \& Choi, J. T. (2013). Home visitation program for detecting, evaluating and treating socially withdrawn youth in Korea. Psychiatry and Clinical Neuroscience, 67, 193-202.

牧 亮太・海田梨香子・湯澤正通 (2010)。ひきこもり 親和性の高い大学生に扔ける心理的特徴の検討— 友人関倸, 不快情動回避傾向, 早期完了特徵との関 連について—広島大学心理学研究, 10,71-80.
松枝れい.島田英昭 (2010). 対人的自己効力感を向上 させるプログラムの開発 信州心理臨床紀要, 9, 33-38.

松本明生 ·坂野雄二 (2000). 対人的自己効力感と公的 自己意識が社交不安に及ぼす影響 日本行動療法学 会第26回大会発表論文集, 160-161.

松尾直博・新井邦二郎 (1998). 坚童の対人不安傾向と 公的自己意識, 対人不安傾向との関係 教育心理学 研究, 46, 21-30.

水田一郎 - 小林哲郎 - 石谷真一 - 安住伸子 - 井出草 平・谷口由利子 (2009). 大学生に見出されるひきこ もりの精神医学的な実態把握と援助に関する研究 平成 20 年度厚生労働科学研究費補助金（こころの健 康科学研究事業)「思春期のひきこもりをもたらす精 神疾患の実態把握と精神医学的治療・援助システム の構築に関する研究」

Moe, K. O., \& Zeiss, A. M. (1982). Measuring self-efficacy expectations for social skills: A methodological inquiry. Cognitive Therapy and Research, 6, 191-205.

Muris, P. (2002). Relationships between self-efficacy and symptoms of anxiety disorders and depression in a normal adolescent sample. Personality and Individual Differences, 32, 337-348.

Nagata, T., Yamada, H., Teo, A. R., Yoshimura, C., Nakajima, T., \& van Vliet, I. (2011). Comorbid social withdrawal (hikikomori) in outpatients with social anxiety disorder: Clinical characteristics and treatment response in a case series. International Journal of Social Psychiatry, 59, 73-78.

内閣府政策統括官 (2010), 若者の意識に関する調査 （ひきこもりに関する実態調查）報告書 内閣府政策 統括官（共生社会政策担当）

丹羽奈緒 · 濱口真奈 $\cdot$ 村上菜々子・嶋田洋徳 $\cdot$ 菅野 純（2007）。不登校児童生徒を対象としたキャンプ活 動が抑うつ・不安および対人的自己効力感に及ぼす 影響 日本教育心理学会第 49 回総会発表論文集, 287.

岡島 義·金井嘉宏・陳 峻雯・坂野雄二 (2007). 社 交不安障害に求ける恐怖場面内での回避行動の評価 —Avoidance Behavior In-Situation の開発—— 行 動療法研究, 33, 1-12.

大野 裕 (2002). 対人恐怖症と社会不安障害の類似点 と相違点 樋口輝彦・ 久保木富房 - 不安 ·抑うつ臨 床研究会 (編) 社会不安障害 日本評論社 pp. 113-125. 
齋藤万比古 $\cdot$ 中島豊爾 · 伊藤順一郎 - 皆川邦直 $\cdot$ 弘中 正美 · 近藤直司 · 水田一郎 · 奥村雄介 - 清田晃生 · 渡部京太・原田 豊·斎藤 環 ·堀口逸子 (2010). ひきこもりの評価・支援に関するガイドライン 平 成 21 年度厚生労働科学研究費補助金（こころの健康 科学研究事業)「思春期ひきこもりをもたらす精神科 疾患の実態把握と精神医学的治療・援助システムの 構築に関する研究」

佐藤 優 ·鈴木俊太郎 (2012). 対人的自己効力感を向 上させるリソースに着目したプログラムの作成 信 州心理臨床紀要, 11, 23-32.

境 泉洋・陳 峻雯 (2007). ひきこもり状態と社会不 安症状の関連 日本行動療法学会第 33 回大会発表論 文集，138-139.

境 泉洋 - 川原一紗 - 木下龍三 - 久保祥子. 若松清 江・NPO法人全国引きこもり KHJ 親の会 (2009). $\mathrm{NPO}$ 法人全国引きこもり $\mathrm{KHJ}$ 親の会「引きこもり」 の実態に関する調査報告書 (6) : 全国引きこもり $\mathrm{KHJ}$ 親の会における実態 徳島大学総合科学部境研究室, 24-40.

Schwarzer, R., \& Jerusalem, M. (1992). Advances in anxiety theory: A cognitive process approach. In K. A. Hagtvet \& T. B. Johnsen (Eds.), Advances in test anxiety research. Vol. 7. Amsterdam, The Nehterlands: Swets \& Zeitliger. pp. 2-17.
椎葉亮一 (2002). CSSTによる対人的自己効力感の促 進 日本教育心理学会第 44 回総会発表論文集, 81 .

Teo, A. R. (2012). Social isolation associated with depression: A case report of hikikomori. International Journal of Social Psychiatry, 59, 339-341.

東京都青少年 ·治安対策本部 (2008). 実態調査からみ るひきこもる若者のこころ 平成 19 年度若年者自立 支援調査研究報告書 東京都青少年 ·治安対策本部 総合対策部若年者課

東京都青少年 ·治安対策本部（2009）。ひきこもる若者 と家族の悩み平成 20 年度若年者自立支援調查研究 報告書 東京都青少年 - 治安対策本部総合対策部若 年者課

東京都青少年・治安対策本部（2010）。若者に社会不適 応をもたらさないために一若者の心情を理解した 関わりについて——ひきこもり等に関する年齢別 未然防止対策調査検討報告書 東京都青少年 ·治安 対策本部総合対策部若年者課

渡部麻美・松井 豊・高塚雄介（2010）。ひきこもりお よびひきこもり親和性を規定する要因の検討 心理 学研究, 81, 478-484.

渡部麻美 · 松井 豊・高塚雄介 (2011)。ひきこもり親 和群の下位類型—ひきこもりへの移行可能性に注 目して——筑波大学心理学研究, 42, 51-57.

-2014.3.9受稿, 2014.12.12受理一 


\title{
The Effects of Social Anxiety Symptoms and Social Self-Efficacy on Affinity for Social Withdrawal in University Students
}

\author{
Hiromichi Arai ${ }^{1}$, Yuasa Hironaka ${ }^{2}$ and Kiyomi Kondo ${ }^{3}$ \\ ${ }^{1}$ Graduate School of Human Services, Hokusho University \\ ${ }^{2}$ Sapporo Hana Developmental Psychiatry Day Service \\ ${ }^{3}$ Graduate School of Psychology, Tokyo University and Graduate School of Social Welfare \\ The Japanese Journal of Personality 2015, Vol. 24 No. 1, 1-14
}

This study examined the relationships among affinity for social withdrawal, social anxiety, and social selfefficacy based on a cognitive model of social phobia (Clark \& Wells, 1995). Undergraduate students (101 males and 145 females) completed a self-report questionnaire assessing affinity for social withdrawal, social anxiety symptoms (fear of social situations, and avoidance of social situations) and social self-efficacy. Covariance structural analysis indicated that fear of social situations was positively associated with affinity for social withdrawal. In contrast, the results did not indicate that avoidance of social situations was associated with affinity for social withdrawal. In addition, the results indicated that social self-efficacy was negatively associated with affinity for social withdrawal via fear of social situations. These results suggest that preventive intervention strategies targeting social self-efficacy might be useful in decreasing affinity for social withdrawal.

Key words: affinity for social withdrawal, social anxiety, social self-efficacy, university students 